\title{
Distribution, ecology and conservation of an endangered Andean hummingbird: the Violet-throated Metaltail (Metallura baroni)
}

\author{
BORIS A. TINOCO, PEDRO X. ASTUDILLO, STEVEN C. LATTA and \\ CATHERINE H. GRAHAM
}

\section{Summary}

The Violet-throated Metaltail Metallura baroni is a high altitude hummingbird endemic to south-central Ecuador currently considered globally 'Endangered'. Here we present the first detailed assessment of its distribution, ecology and conservation. We first used a maximum entropy model (Maxent model) to create a predicted distribution for this species based on very limited species occurrence data. We used this model to guide field surveys for the species between April and October 2006. We found a positive relationship between model values and species presence, indicating that the model was a useful tool to predict species occurrence and guide exploration. In the sites where the metaltail was found we gathered data on its habitat requirements, food resources and behaviour. Our results indicate that Violet-throated Metaltail is restricted to the Western Cordillera of the Andes Mountains in Azuay and Cañar provinces of Ecuador, with an area of extent of less than $2,000 \mathrm{~km}^{2}$. Deep river canyons to the north and south, lack of suitable habitat, and potential interspecific competition in the east may limit the bird's distribution. The species occurred in three distinct habitats, including Polylepis woodland, the upper edge of the montane forest, and in shrubby paramo, but we found no difference in relative abundance among these habitats. The metaltail seems to tolerate moderate human intervention in its habitats as long as some native brushy cover is maintained. We found that Brachyotum sp., Berberis sp., and Barnadesia sp. were important nectar resources. The 'Endangered' status of this species is supported due to its restricted distribution in fragmented habitats which are under increasing human pressures.

\section{Resumen}

El Metalura Gorjivioleta Metallura baroni es un colibrí de altura endémico al sur centro de Ecuador y considerado globalmente En Peligro. En este trabajo presentamos el primer estudio que evalúa su distribución, ecología y conservación. Como primer paso creamos un modelo potencial de distribución de la especie utilizando el método de máxima entropía (Maxent) basado en la escasa información sobre sus localidades de presencia. Este modelo sirvió como base para realizar exploraciones de campo en búsquela de la especie entre Abril y Octubre del 2006. Encontramos una relación positiva entre los valores del modelo y los sitios de presencia de la especie, indicando que el modelo fue útil para predecir su ocurrencia y guiar las exploraciones. En los sitios en donde encontramos a metalura obtuvimos datos sobre sus requerimientos de hábitat, recursos alimenticios y comportamiento. Los resultados indican que Metalura Gorjivioleta está restringido a la Cordillera Occidental del los Andes en la provincias de Azuay y Cañar en el Ecuador, en un área menor a 2,00o $\mathrm{km}^{2}$. Depresiones geográficas por la presencia de ríos hacia el norte y sur, la escasez de hábitat y competencia interespecífica hacia el este podrían limitar la 
distribución de la especie. La especie ocupó tres tipos de hábitat, incluyendo bosques de Polylepis, el límite superior de bosque montano y páramo arbustivo, pero no encontramos diferencia en su abundancia relativa entre estos hábitat. Al parecer metalura soporta ciertos niveles de intervención humana en sus hábitat, siempre y cuando exista algo de cobertura de arbustos nativos. Entre sus recursos importantes de néctar encontramos a Brachyotum sp., Berberis sp., y Barnadesia sp. Respaldamos la categoría de En Peligro de la especie debido a su rango de distribución en hábitat fragmentados y con una creciente presión humana.

\section{Introduction}

Hummingbirds of the genus Metallura are among several taxonomic groups that have radiated in the Andes Mountains (Graves 1980, García-Moreno et al. 1999). Metallura comprises nine species whose ranges tend to replace each other with elevation and latitude from Venezuela to northern Chile (Fjeldså and Krabbe 1990). Among these species is the Violet-throated Metaltail Metallura baroni, a high Andean species considered globally 'Endangered' (BirdLife International 2004) because of its restricted distributional range in south-central Ecuador (Fjeldså and Krabbe 1990, Ridgely and Greenfield 2001). Until the late twentieth century, this species was known only from a few reports, but more recently the bird has been detected during surveys conducted in the mountains of Cajas National Park, Mazán Protection Forest, and surrounding areas in Azuay province (Ortiz-Crespo 1984, King 1989, Rodas 1998). While these surveys yielded additional reports of the Violet-throated Metaltail, they did little to clarify its range, habitat requirements or ecology. The few published reports that exist have focused on general characteristics of its habitat, and the use of some nectar resources (Ortiz-Crespo 1984, Fjeldsa and Krabbe 1990, Rodas 1998, Ridgely and Greenfield 2001). A more complete knowledge of the Violet-throated Metaltail's geographic distribution, ecological requirements and potential factors limiting its population size is essential to protect and manage this species (Matheus 2002). Here we present the first comprehensive survey of the distribution and status of the Violet-throated Metaltail. We combine computer modelling to predict the geographic range of the species, with field work to verify our prediction, and we collect additional ecological and behavioural data of habitat use at local scales.

The use of species distribution modelling has been advocated as a tool to guide exploration of the geographic distribution of poorly known species (Graham et al. 2004a, Soberón and Peterson 2004). Nonetheless, there has been little work to determine if it is indeed a valid tool for this application, especially in topographically complex and poorly studied regions where it is perhaps most useful. We used available occurrence records of the Violet-throated Metaltail to create a species distribution model to extrapolate its potential geographic range. We used this prediction to guide intensive searches across the potential range of the species. In order to evaluate the influence of human land-use on the study species' distribution and abundance, we surveyed both natural and human-influenced habitats. We also gathered detailed behavioural observations and quantified food resources and habitat characteristics in regions where we observed the species. We conclude with recommendations for the conservation of this narrowly distributed Andean endemic.

\section{Methods}

\section{Study Area}

We conducted this study at elevations of 3,000-4,100 $\mathrm{m}$ in both Western and Eastern Cordilleras of the Andes Mountains in south-central Ecuador in Azuay, Cañar and Morona-Santiago provinces. This area receives $1,200-1,500 \mathrm{~mm}$ of precipitation annually, with more rain towards the Eastern Cordillera. Daily temperatures can fluctuate greatly, often changing from $0-20^{\circ} \mathrm{C}$, while the monthly mean temperature varies from $5-12^{\circ} \mathrm{C}$ (IERSE 2004). 
The topography of the area is markedly irregular. On the interior flanks of the Andes, slopes can be in the range of 30-60\%, while on the exterior flanks they may exceed $60 \%$ (White and Maldonado 1991). Evidence of the effects of the last glacial maximum is widespread, especially in the Western Cordillera where remnant glacial lakes, U-shaped valleys, and glacial cirques are common elements of the landscape (Harden and Borrero 2005).

The study area has two major vegetation types above 3,00o $\mathrm{m}$ : high montane forest, and paramo which consists of grassland in the east and grassland and Polylepis forest fragments in the west (Baquero et al. 2004). In addition, the upper elevation edge of montane forest represents a distinct ecotone. Human induced disturbance is widespread in the area so that native montane forest is now confined to the least accessible areas (Vanacker et al. 2007). Likewise, the paramo is frequently used for ranching and agriculture. Burning of the grass to promote regeneration is an ancient tradition that is still widely employed (White and Maldonado 1991).

\section{Species Distribution Models}

Because the range of the species was poorly known and suitable habitat seemed to occur beyond the known range of Violet-throated Metaltail (Matheus 2002, BirdLife International 2004), we first used species distributional modelling to select geographic areas for intensive searches of suspected range extensions, and to determine focal sites for ecological studies of the species. In species distribution modelling, environmental conditions associated with known bird occurrences plotted on GIS-based climatic maps are used to build a statistical model to predict regions of suitable habitat. Hence, modelling requires two kinds of data: occurrence records of the study species and environmental variables.

Occurrence records were taken from Abbruzzese et al. (1996), Rodas and Tinoco (2003), Hobson et al. (2003), collections of the Museo Ecuatoriano de Ciencias Naturales (MECN) in Quito, Ecuador, and pre-field work personal observations of the authors. This yielded 13 unique georeferenced Violet-throated Metaltail occurrences. Climatic data for modelling came from Hijmans et al. (2005) with a grid size of $\mathrm{I} \mathrm{km}^{2}$. While this resolution may be too coarse to capture all environmental variation in this topographically complex region, we assume that it provides useful information at the scale of the species' geographic range. We used eight environmental layers for the predicted model which summarized annual means and variation in climate, including mean annual temperature, temperature seasonality, mean temperature of the coldest quarter, mean temperature of the warmest quarter, annual precipitation, precipitation seasonality, precipitation of the wettest quarter, and precipitation of the driest quarter.

We used the maximum entropy model (Maxent) to model the distribution of the species (version 2.3, Phillips et al. 2006). This method uses occurrence data to create distributional models, and has proven to be robust and precise compared to other methods (Elith et al. 2006). The method also produces useful models with small sample sizes (Phillips et al. 2006; Hernandez et al. 2006), and so is especially valuable for exploratory research. The environmental variable values at the presence localities impose constraints on the unknown distribution such that the mean and variance of the environmental variables in the model prediction are close to the empirical values of the occurrence data. Put more technically, the maximum entropy approach then approximates an unknown distribution using the known occurrences and background points (all points/grid cell values in the study region) that maximizes entropy, subject to the constraints imposed by the known occurrences. The result of Maxent shows a map where every grid has a value of $0-100$; this represents the relative suitability (not probability, as we have no absence data) of species occurrence (Phillips et al. 2006). Maxent is not strongly influenced by the number of environmental parameters used to build models because it ignores those that are noninformative, and uses regularization techniques to avoid over-parameterization (Phillips et al. 2006). Nonetheless, while a large number of predictor environmental variables can be used to create a distribution model, care should be used in drawing biological inference about the importance of individual variables. We used Maxent only to build a model, not to draw inference. 
We evaluated the model using a single partition where the model was built with ten points and tested with the remaining three points. We used the area under the receiver-operating curve (AUC) to evaluate model performance (Fielding and Bell 1997). We did not conduct a more thorough evaluation because our model was only for exploratory purposes to identify potential regions where the species might exist.

\section{Bird Surveys}

Using our map of suitability values generated by the Maxent model for the potential distribution of the Violet-throated Metaltail (Figure 1), we searched from April to October 2006 in areas predicted to have high suitability to determine if the species was present. We also searched several regions that had low suitability values in north-eastern Azuay and south-eastern Cañar provinces because the species had previously been occasionally reported there (Hobson et al. 2003, L. Navarrete pers. comm.). Two people working together intensively searched 43 sites by walking $96.7 \mathrm{~km}$. Our searches averaged $1.9 \pm 1.7 \mathrm{SD} \mathrm{km}$ per site. These searches were primarily in the Western Cordillera (29 sites and $68.7 \mathrm{~km}$ ), but we also searched in the Eastern Cordillera (I4 sites and $28.0 \mathrm{~km}$ ).

While searching we walked through potential habitat surveying for the species from o6hoo to 13 hoo hrs, registering individual birds by sight or call, and trying to survey each habitat with an

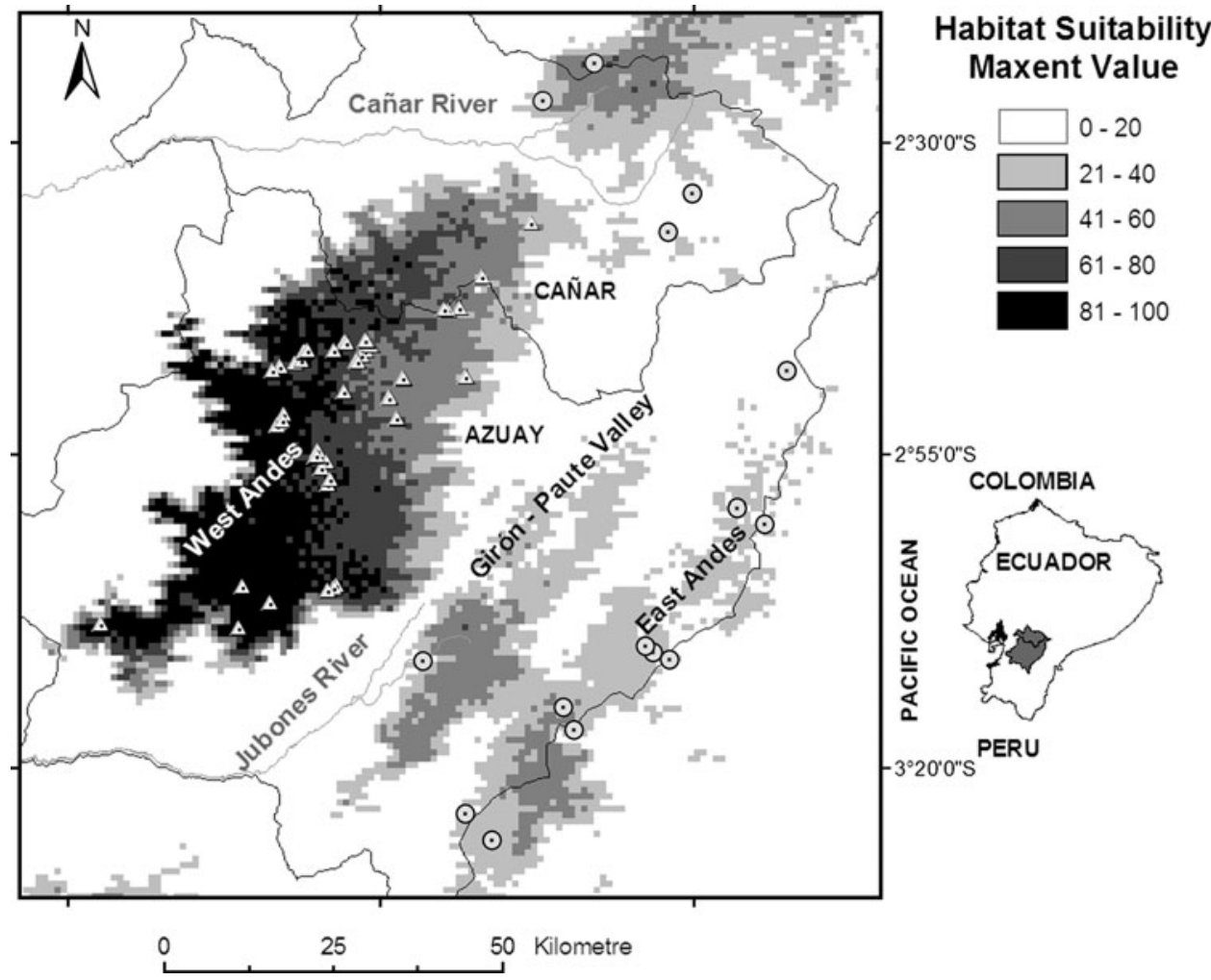

Figure 1. Modelled habitat suitability of Violet-throated Metaltail (Metallura baroni) in southcentral Ecuador using the Maxent method. The $(\Delta)$ represents sites visited where the species was found after confirmation field surveys. The $(O)$ indicates sites visited where the species was not found after validation field surveys. Each survey point represents a mean $1.9 \mathrm{~km}$ route. 
intensity relative to its abundance in the landscape. Concealing habitats, such as dense brush and canopy forest, were also carefully searched. At the end of each day the number of kilometres walked in each habitat type was calculated and recorded by a geographic positioning system (GPS). The conservation status of each transect completed in each habitat type was evaluated visually and classified as: 'not disturbed' when no signs of disturbance were evident; 'moderately disturbed' when the land was occupied for human productive activities but some native vegetation stands were present; and 'severely disturbed' when human induced degradation was widespread. We were aware that this transect-level classification scheme may mask microhabitat variation that could be important to the species, therefore we tried to select routes within transects such that the level of disturbance within a transect was similar.

\section{Ecological Observations}

Behavioural data were gathered each time an individual was observed and for as long as the bird was in view. Activities were classified as: perching, preening, foraging for nectar, and foraging for arthropods. Each activity was characterized by recording, where possible, the height of the bird above the ground, focal plant species used, and total height of the focal plant species. We also quantified the vertical vegetation structure with a foliage height profile at each observation by establishing a $20 \mathrm{~m}$ radius plot centred on the exact location where a bird was first observed. We used a GPS to record the location of this occurrence. Within this plot we established four transects: one each to the north, south, east and west. At each 4-m interval along these transects we used a marked, $3-\mathrm{m}$ pole and recorded the presence or absence of vegetation touching the pole at $0.5 \mathrm{~m}$ intervals from o-3 $\mathrm{m}$. Beyond $3 \mathrm{~m}$ we visually estimated the presence or absence of vegetation at $1 \mathrm{~m}$ intervals until reaching the top of the canopy. Finally, broad scale habitat characteristics were recorded including dominant vegetation type and canopy height.

\section{Statistical Analyses}

We used XLSTAT-Pro version 7.5 (Addinsoft 2004) software for all statistical analyses with alpha $=0.05$. We used the hummingbird encounter rate per $\mathrm{km}$ travelled as an index of the relative abundance of the species in each type of habitat. The Kruskal-Wallis test (Zar 1984) was used to test for a difference in relative abundance of hummingbirds among habitats, and a MannWhitney $U$-test (Zar 1984) was used to compare the relative abundance of the species among habitats with different conservation status.

To explore habitat use and behaviour by this species we used association data garnered only from the second observed manoeuvre by each focal individual to avoid a bias towards the more conspicuous behavioural manoeuvres and to avoid the lack of independence associated with sequential observations (Hejl et al. 1990). We used a chi-square test (Zar 1984) to explore the difference in behaviours among habitats.

\section{Results}

\section{Distribution}

We collected 95 visual and audio occurrences of the Violet-throated Metaltail. Our records included observations on both slopes of the Western Andes at elevations ranging from 3,1504,00o m. The northern limit for the species was at the Río Cañar canyon in Cañar Province. From there and to the south we consistently recorded the species throughout the mountains, with our southernmost record occurring at Narihuiña, just before the Western Andes descend to meet the Río Jubones canyon.

Our distribution model performed well based on our single partition (AUC $=0.993)$. All of the sites in the Western Andes where the hummingbird was found to be present were predicted by 
Maxent to have a relatively high suitability (mean $=66.01 \pm 22.55 \mathrm{SD}$ ) for the species (Figure 1 ). We did not find the species at sites of low suitability (mean $=14.26 \pm 10.23 \mathrm{SD}$ ) in the Eastern Andes.

To obtain the most accurate final distribution model of the hummingbird we reran our model with 68 independent occurrence records in which we imposed a threshold to estimate the extent of occurrence of the species. There is considerable debate, and little advice, on the best method to choose a threshold, especially for occurrence only data (Loiselle et al. 2003, Lui et al. 2005). Pixels with a cumulative value $\geq 40$ were chosen to represent the extent of distribution of the species based on the 1o percentile threshold value (i.e., $90 \%$ of the points were contained within the predicted area). While this threshold could increase the omission rate (sites predicted as negative where the species is truly present; Fielding and Bell 1997, Fielding 2002, Loiselle et al. 2003), we wanted to be conservative given the environmental complexity of the region. The resulting distribution of the species covered $1,86 \mathrm{I} \mathrm{km}^{2}$ (Figure 2). The area of occupancy is likely less than that, however, due to habitat limitations (see Habitat below) which generates patchiness in the distribution of the species within this broader predicted range.

Most of our records of the species are from sites above 3,300 m elevation, but we collected evidence that suggests that at least some Violet-throated Metaltails migrate altitudinally, moving to lower elevations near $3,000 \mathrm{~m}$ during the second half of the year. Some support for this observation comes from a constant-effort bird ringing programme that we operated during the same time period in the Llaviuco sector of Cajas National Park at 3,150 m. We caught nine

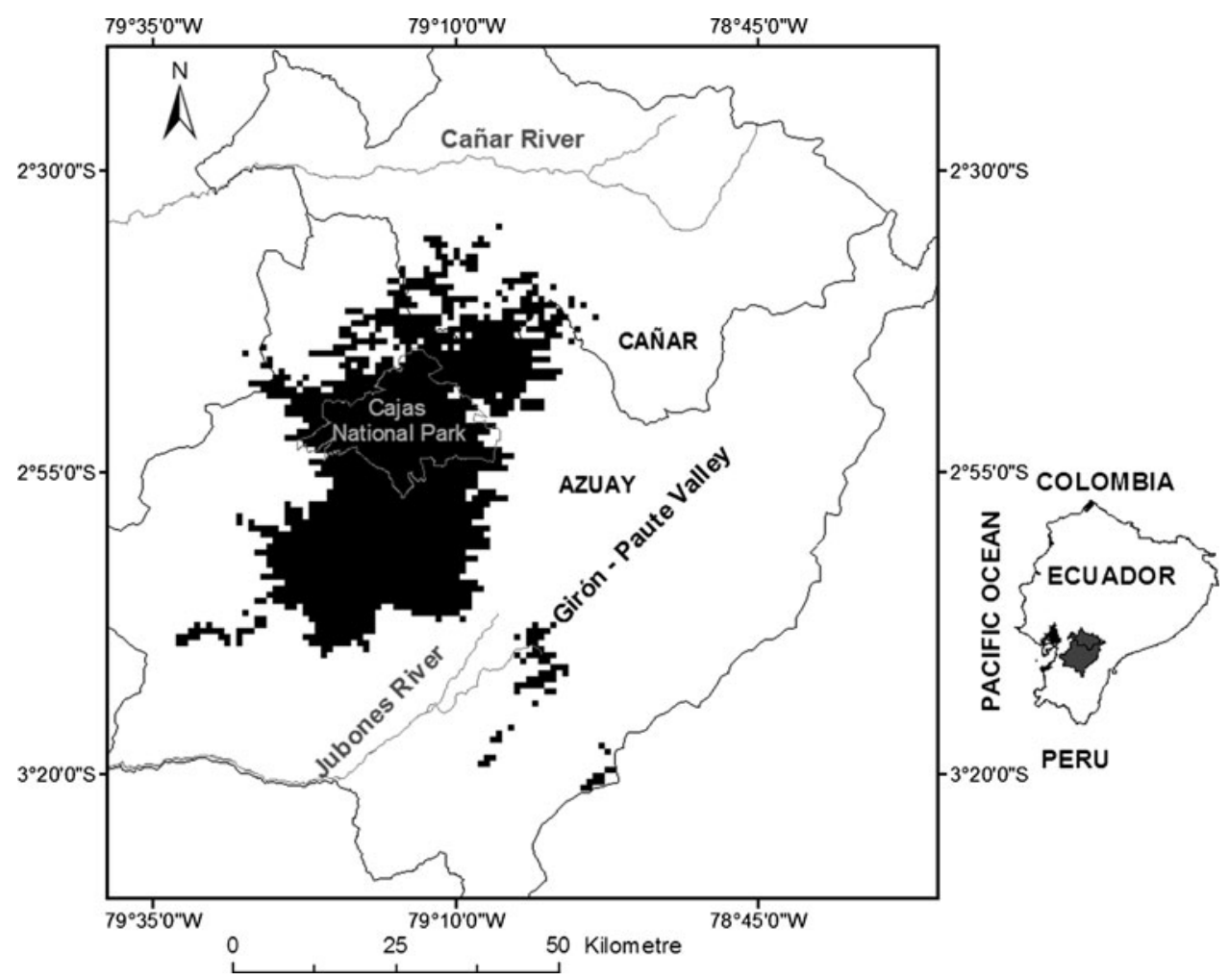

Figure 2. Modelled distribution of Violet-throated Metaltail Metallura baroni using the full occurrence dataset after field validation surveys. The Maxent method was used for modelling and the 10 percentile threshold value was chosen. 
individuals in July 2006 and three in November 2006, but only one was caught in March 2006 and one in March 2007. None of these birds were recaptures.

\section{Habitat}

The Violet-throated Metaltail was found inhabiting all three types of vegetation: Polylepis forest and shrubby paramo, as well as the upper elevation edge of montane forest. However, the species did not prefer any one of these three types of habitats $\left(\chi_{2}^{2}=1.64, P=0.51\right.$; Table 1$)$. None of these habitats are continuous in the Western Andes, but are scattered throughout our study area. We found suitable hummingbird habitat intermixed with open paramo, and habitat also intermixed with severely disturbed habitats including extensive cattle pastures and mature exotic pine plantations where the species was not found (Table 2).

The relative abundance of this species between disturbed and moderately disturbed sites was similar $(Z=1.960, P=0.90$; Table 2), indicating the birds' presence as long as the habitats still contain significant amounts of native vegetation. Human activities in the moderately disturbed habitats included clearings for farming, wood extraction, cattle grazing, young pine forest plantations, and paths made by tourists. All of these plots still contained native bushes and trees where the Violet-throated Metaltail was found.

We recorded detailed habitat characteristics around 58 individuals whose exact location on a particular perch or foraging substrate could be determined with certainty. The mean height of the canopy in habitat used by these birds did not exceed $2.3 \mathrm{~m}$ at any of the sites, indicating the dominance of shrubs in activity areas. In general, Polylepis and montane forests in the study areas usually have a mean canopy height higher than the $2.05 \pm 1.44$ SD m we found (BAT, pers. obs.), but $86 \%$ of our observations from these habitats came from the border areas where a higher percentage of mixed species of shrubs contribute to a lower mean canopy height. Nonetheless, these results should be viewed conservatively because birds are more conspicuous in shrubs than in forest interior.

Foliage height profiles from the three habitats revealed a similar vegetation structure (Figure 3), with a high percentage of vegetation cover in the lowest strata. This indicates that Violet-throated Metaltails' habitats are mainly shrubby, with only a few scattered trees.

\section{Behaviour}

Based on results from the second behavioural observation for each of 58 birds, $52 \%$ (30) of the metaltails observed were foraging, while $48 \%$ (28) were perching. Of the foraging individuals, $70 \%$ (21) were observed feeding on nectar resources, while $30 \%$ (9) were foraging for arthropods. The number of foraging attempts for nectar or arthropods among shrubby paramo, Polylepis forest, and upper edge of montane forest sites did not differ significantly $\left(\chi_{2}^{2}=5.99, P=0.29\right)$, indicating that foraging strategies were similar among habitats. We found the species feeding on

Table 1. Encounter rates in three habitats occupied by the Violet-throated Metaltail Metallura baroni in south-central Ecuador.

\begin{tabular}{llll}
\hline Habitat & $\begin{array}{l}\text { Cumulative } \\
\text { survey length } \\
(\mathrm{km})\end{array}$ & $\begin{array}{l}\text { Number of } \\
\text { Violet- } \\
\text { throated } \\
\text { Metaltail } \\
\text { registered }\end{array}$ & $\begin{array}{l}\text { Violet- } \\
\text { throated } \\
\text { Metaltail km }\end{array}$ \\
\hline Shrubby paramo & 14.6 & 29 & \\
Polylepis forest & 26.3 & 56 & 2.0 \\
Upper edge of montane forest & 17.8 & 31 & 2.1 \\
\hline
\end{tabular}


Table 2. Encounter rates of Violet-Throated Metaltail Metallura baroni in habitats of different conservation status in south central Ecuador.

\begin{tabular}{llll}
\hline Habitat & $\begin{array}{l}\text { Survey } \\
\text { length }(\mathrm{km})\end{array}$ & $\begin{array}{l}\text { Number of } \\
\text { Violet- } \\
\text { throated } \\
\text { Metaltail } \\
\text { registered }\end{array}$ & $\begin{array}{l}\text { Violet- } \\
\text { throated } \\
\text { Metaltail km }\end{array}$ \\
& & 48 & \\
\hline Not Disturbed & 24.0 & 68 & 2.0 \\
Moderately Disturbed & 34.7 & 0 & 2.0 \\
Severely Disturbed & 10.0 & & 0 \\
\hline
\end{tabular}

the flowers of nine plant species. Brachyotum sp. (Melastomataceae) was the most commonly visited plant ( $42 \%$ of observations), with Berberis sp. (Berberidaceae; $18 \%$ ) and Barnadesia arborea (Asteraceae; 10\%) also receiving frequent visits. Other plant species utilized by the metaltail included Draba sp. (Brassicaceae), Gentianella sp. (Gentianaceae), Ribes lehmannii (Grossulariaceae), Salvia sp. (Lamiaceae), Saracha quitensis (Solanaceae), and Solanum sp. (Solanaceae).

We found that Violet-throated Metaltail fed on arthropods occurring on three types of substrates: vegetation (including Brugmansia sp., Gynoxis sp., and Valeriana sp.), moss (on the ground), and in the air. The manoeuvres that metaltails employed to capture prey items varied among substrates. Following Remsen and Robinson (1990) and Stiles (1995), these techniques included hover-gleaning on vegetation $(67 \%$ of observations), sally-pouncing on ground mosses $(25 \%)$, and sally-hawking in the air $(8 \%)$.

Across all habitats and foraging methods, Violet-throated Metaltails foraged at a mean height of $1.35 \pm 1.88 \mathrm{SD} \mathrm{m}(n=30)$. Fifty percent of the foraging activities were $<1 \mathrm{~m}$ in height; $23 \%$ occurred at $1-2 \mathrm{~m} ; 20 \%$ were observed at $2-3 \mathrm{~m}$; and $7 \%$ of foraging actions were $>3 \mathrm{~m}$ from the ground (Figure 4). The maximum height of all substrates where the species foraged was a mean $1.87 \mathrm{~m} \pm 2.33 \mathrm{SD}$.

The Violet-throated Metaltail was observed perched on the top of shrubs or at the end of exposed branches at a mean height above ground of $2.07 \mathrm{~m} \pm 1$.11 SD $(n=28)$. In $11 \%$ of the observations the perch site was $<1 \mathrm{~m}$ in height. Thirty-two percent of perch sites were at $1-2 \mathrm{~m}$; $25 \%$ of records were from $2-3 \mathrm{~m} ; 21 \%$ were at $3-4 \mathrm{~m}$; and $11 \%$ of perch birds were recorded at 4-5 $\mathrm{m}$ (Figure 4). The total height of the substrates where Violet-throated Metaltail perched was a mean 2.84 $\pm 1.56 \mathrm{SD}$ m. Gynoxis (Asteraceae), Polylepis (Rosaseae) and Escallonia (Escalloniaceae) were the most common plant species where the species perched.

On four occasions between June and July we observed what appeared to be courtship display behaviour for the species. A male and female bird moved through the foliage chasing each other while making frequent vocalizations. The female then perched on an exposed branch while the male hovered in front of her, making a series of flights of about $2 \mathrm{~m}$ each in multiple directions. After each short flight the male returned again in front of the female where he hovered for less than $3 \mathrm{sec}$. The total display lasted approximately $20 \mathrm{sec}$.

\section{Discussion}

Violet-throated Metaltail was found exclusively in the Western Cordillera of the Andes. Its area of extent appears to be restricted by two deep canyons cutting the Andes at Río Cañar to the north and Río Jubones to the south. The barrier effect of deep river valleys on the expansion of bird ranges has been recognized before (Poulsen and Krabbe 1998). Further, Jorgensen et al. (1995) postulated that the Giron-Paute Valley, located between the Western and Eastern Cordilleras, represented a dispersal barrier during both the glacial and interglacial periods. Speciation 


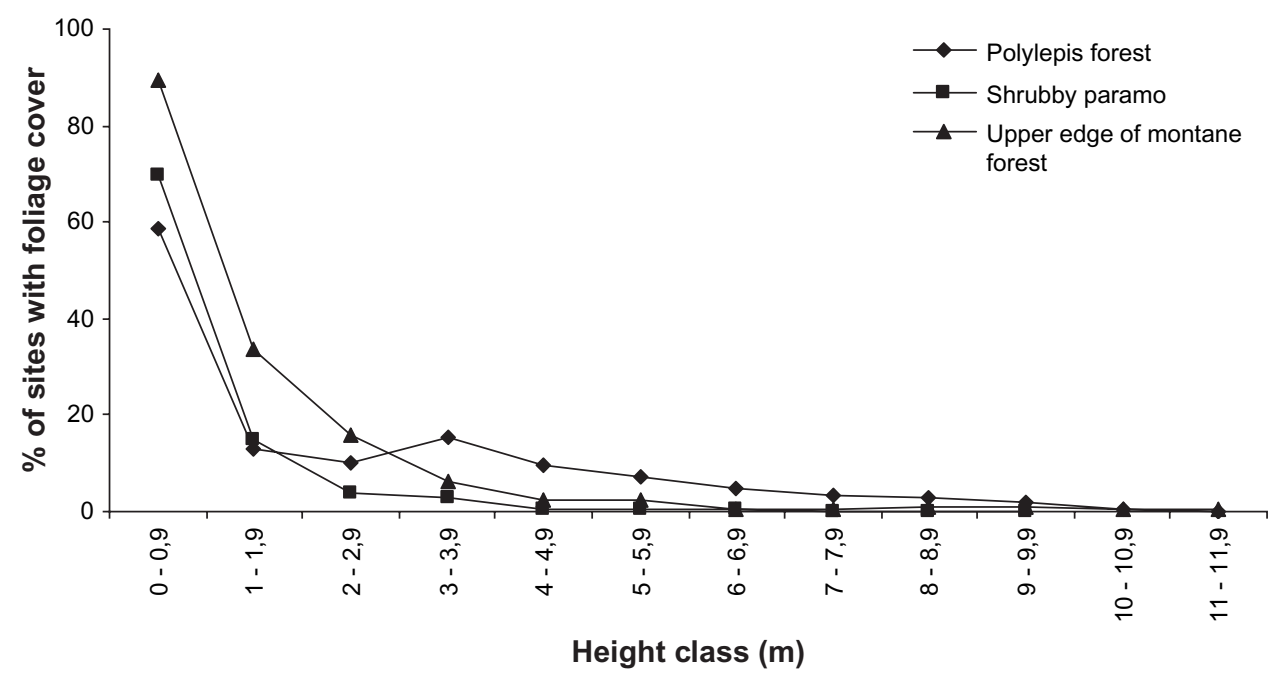

Figure 3. Foliage height profiles in the three habitats used by Violet-throated Metaltail Metallura baroni in south-central Ecuador.

processes in the high Andes are thought to be the result of dispersal during interglacial periods when habitat was likely more extensive, followed by isolation and extinction of populations during colder and drier Pleistocene glacial periods (Graves 1980, Barnett 1997, Graham et al. 2004b, Pérez-Emán 2005, Weir 2006, Cadena et al. 2007). Therefore, the above-mentioned barriers may have influenced speciation processes in the Western Andes of Azuay and Cañar provinces which has seven other endemic vertebrate species (two rodents and five frogs) in addition to the Violet-throated Metaltail (Martínez et al. 2005).

Even though we searched extensively for the Violet-throated Metaltail in the Eastern Cordillera of the Andes, we were not able to confirm its presence there. The Eastern Cordillera in Azuay Province is regularly visited by birdwatching tours and research expeditions, but we are aware of only three reports of the species in this area (Ridgely and Greenfield 2001, Hobson et al. 2003, L. Navarrete pers. comm.). It appears that the presence of the species in the Eastern Andes is not regular, and that those reports might come from vagrant individuals which may cross the Andes using a high altitude transverse corridor present in Cañar, north of the study area (Poulsen and Krabbe 1998).

We believe that a limiting factor for population establishment of Violet-throated Metaltail in the Eastern Andes could be low habitat suitability in the Eastern Andes as revealed by our Maxent analysis, which also suggested that there are particular climatic conditions prevalent in the Western Andes which distinguish these mountains from the conditions found in the Eastern Andes. In particular, the Western Andes are drier than the Eastern Andes.

Another limiting factor in determining the distribution of the Violet-throated Metaltail may be competition with its congener, the Viridian Metaltail M. williami, which is a very common hummingbird in the area and has similar ecological requirements (Fjeldså and Krabbe 1990, García-Moreno et al. 1999). From our observations, the Viridian Metaltail exhibits territorial behaviour and responds extremely aggressively to playback of Violet-throated Metaltail vocalizations. The low productivity, reduced resource base, and short stature of vegetation at higher elevations, are factors which likely constrain the possibility of coexistence of sister taxa in the high Andes (Graves 1985).

We did not find differences in the relative abundance of Violet-throated Metaltails among Polylepis forest, shrubby paramo, and the upper elevation edge of montane forest. This is likely 


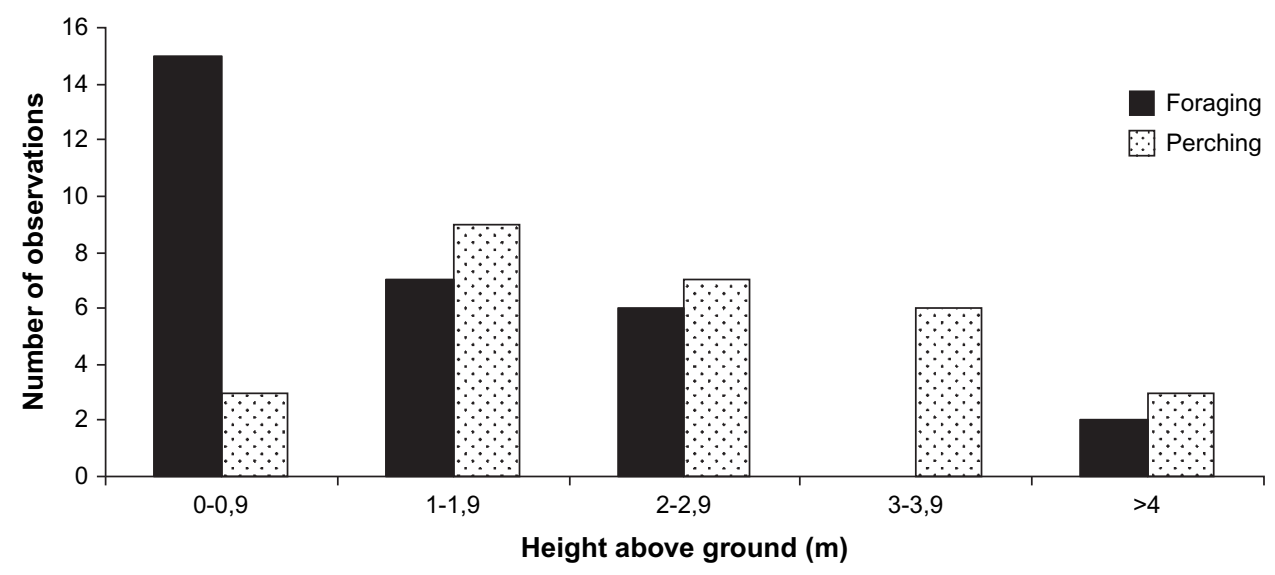

Figure 4. Heights above ground of the foraging and perching activities observed for the Violetthroated Metaltail Metallura baroni in south-central Ecuador.

because the foliage height profiles were similar among habitats and moreover, important food resources, including Brachyotum and Berberis, can occur in a variety of habitat types above $3000 \mathrm{~m}$ elevation throughout the Ecuadorian Andes (Jorgensen and León-Yánez 1999). Given that habitat structure and food resources often determine habitat selection of a species (Petit and Petit 1996), it is not surprising that relative abundances were similar. Nonetheless, this does not conclusively indicate that all habitats are equally suitable. Abundance related parameters are not always good indicators of habitat quality for a species (Van Horne 1983); thus, direct measures of fitness (i.e. reproductive success, home range size, and survival) and population structure (sex and age ratios) are needed to fully evaluate the quality of habitats for the species (López-Ornat and Greenberg 1990, Latta and Baltz 1997, Humple et al. 2001).

The Violet-throated Metaltail most often visited flowers of Brachyotum sp., Berberis sp., and Barnadesia arborea. These tree species are known to be a common nectar resource for other Metallura species in the high Andes (Fjeldså and Krabbe 1990). King (1989) reported Castilleja fissifolia (Scrophulariaceae) as the most important flower for Violet-throated Metaltail during July-October, but in our research we did not observe metaltails feeding on this species, suggesting that there may be seasonal differences in resource use among habitats.

Consumption of arthropods is a well known behaviour for hummingbirds. Although rates of insectivory differ among species (Kuban and Neill 1980, Remsen et al. 1986), their importance in the diet is thought to increase with elevation (Remsen et al. 1986) because nectar concentrations in flowers are more dilute in the highlands than in the lowlands (Wolf et al. 1976). In contrast, Stiles (1995) reported that foraging on arthropods comprised nearly $50 \%$ of the foraging attempts by a hummingbirds in lowland Costa Rica - a much higher rate of insectivory than the $30 \%$ that we found for the high elevation Violet-throated Metaltail. Unfortunately, few other data are available on insectivory across elevational gradients.

\section{Conservation}

The Violet-throated Metaltail is considered 'Endangered' at national and global scales (Granizo et al. 2002, Birdlife International 2004) on the basis that it occurs in fragmented habitats over an area of $<5,000 \mathrm{~km}^{2}$ and the population is presumed to be in continuous decline. Indeed, our study confirms that the species has a very patchy distribution across its extent of occurrence of less than $2,000 \mathrm{~km}^{2}$, and its habitat is under increasing pressure from human activities such as 
road construction, cattle ranching, burning and wood extraction. Cajas National Park and the nearby Mazán Protection Forest are the only protected areas within the Violet-throated Metaltail range that actually have conservation plans (both sites are managed by the local public water and telephone company, ETAPA), and these two areas comprise $<10 \%$ of the species' extent of occurrence (Figure 2). The species was also registered in two other Protection Forests, Sunsún-Yanasacha and Yanuncay-Irquis. However, Protection Forests are not part of the national network of protected areas (SNAP) in Ecuador. These reserves also allow for human productive activities within their borders, therefore they do not guarantee the conservation status of the habitats they are supposed to protect (Rodas 2001). Although the Violet-throated Metaltail was found in habitats with some degree of disturbance, these habitats always had some remnants of native vegetation. Given these results we suggest that substantial remnants of native vegetation should be left in landscapes dominated by human activity in order to provide habitat for the species. We also suspect that open paramo and extensive cattle pastures, especially in the northern and southern parts of its range, may limit dispersal of hummingbirds. Continued destruction of shrubby habitats in these regions may lead to further fragmentation of populations and to local extirpations (Brooks et al. 1999, Wiegand et al. 2005).

The information gained in this study on habitat use can be incorporated into our regional Maxent prediction of the species range. Fine scale aerial photographs or remote-sensing imagery could be used to identify the distribution of Polylepis forest, shrubby paramo, and upper elevation edge of montane forest. While this fine-scale mapping and image analysis was beyond the scope of the current study, it may be useful in the future and could lead to new analyses of the conservation status of the Violet-throated Metaltail. For example, genetic information could be used to determine the degree of connectivity among populations isolated in different remnants of suitable habitat across its range. We also suggest that studies of reproductive success and other measures of fitness should be initiated to confirm the relative value of the different habitat types for the Violet-throated Metaltail and the impact of moderate disturbance by humans on hummingbird populations.

\section{Acknowledgments}

We acknowledge the field assistance of Danilo Mejía. Logistic support was provided by Paul Vintimilla and Franklin Bucheli from Parque Nacional Cajas, and by Gustavo Chacón from Universidad del Azuay. Juan Freile, Fabián Rodas, and Stuart Marsden contributed with helpful comments on an early version of this paper. Idea Wild donated some of the field equipment. Funding was provided by Stony Brook University, a NASA New Investigator grant to C.H. Graham, the National Aviary (USA), PRBO Conservation Science, and a grant from Fundación EcoCiencia through Programa de Becas de Investigación para la Conservación (PBIC) to B. A. Tinoco.

\section{References}

Abbruzzese, C., Thomas, B. and Jiménez, G. (1996) Aves de los bosques nublados de la provincia del Azuay. Cuenca, Ecuador: Fundación Mazán.

Addinsoft. (2004) XLSTAT Pro, ver. 7.5. París: Addinsoft SARL.

Baquero, F., Sierra, R., Ordóñez, L., Tipán, M., Espinosa, L., Rivera, M. and Soria, P. (2004) La vegetación de los Andes del Ecuador. Quito: EcoCiencia, CESLA, Cor- poración EcoPar, MAG SIGAGRO, CDCJatun Sacha, División Geográfica-IGM.

Barnett, A. (1997) The ecology and natural history of a fishing mouse Chibchanomys spec. nov. (Ichtyomyini: Muridae) from the Andes of southern Ecuador. Int. J. Mamm. Biol. 62: 43-52.

BirdLife International (2004) Threatened birds of the world. CD-Rom. Cambridge, UK: BirdLife International. 
Brooks, T. M., Pimm, S. L. and Oyugi, J. O. (1999) Time lag between deforestation and bird extinction in tropical forest fragments. Conserv. Biol. 16: 909-923.

Cadena, C. D., Klicka, J. and Ricklefs, R. E. (2007) Evolutionary differentiation in the Neotropical montane region: Molecular phylogenetics and phylogeography of Buarremon brush-finches (Aves, Emberizidae). Mol. Phylogen. Evol. 44: 993-1016.

Elith, J., Graham, C. H., Anderson, R. P., Dudik, M., Ferrier, S., Guisan, A., Hijmans, R. J., Huettman, F., Leathwick, J. R., Lehmann, A., Li, J., Lohmann, L. G., Loiselle, B. A., Mannion, G., Moritz, G., Nakamura, M., Nakazawa, Y., Overton, J. M. M., Peterson, A. T., Phillips, S. J., Richardson, K., ScachettiPereira, R., Schapire, R. E., Soberón, J., Williams, S., Wisz, M. S. and Zimmermann, N. E. (2006) Novel methods improve prediction of specieś distributions from occurrence data. Ecography 29: 129-151.

Fielding, A. H. (2002) What are appropriate characteristics of an accuracy measure? Pp 271-280 in J. M. Scott, P. J. Heglung and M. L. Morrison, eds. Predicting species occurrences: Issues of accuracy and scale. Washington DC: Island Press.

Fielding, A. H. and Bell, J. F. (1997) A review of methods for the assessment of prediction errors in conservation presence/absence models. Environ. Conserv. 24: 38-49.

Fjeldså, J. and Krabbe, N. (1990) Birds of the high Andes. Copenhagen and Svenborg: Zoological Museum, University of Copenhagen and Apollo Books.

García Moreno, J. P., Arctander, J. and Fjeldså, J. (1999) Strong diversification at the treeline among Metallura hummingbirds. Auk 116: 702-711.

Graham, C. H., Ferrier, S., Huettman, F., Moritz, C. and Peterson, A. T. (2004a) New development in museum-based informatics and applications in biodiversity analysis. Trends Ecol. Evol. 19: 497-503.

Graham, C. H., Ron, S. R., Santos, J. C., Schneider, C. J. and Moritz, C. (2004b) Integrating phylogenetics and environmental niche models to explore speciation mechanisms in dendrobatid frogs. Evolution 58 : $1781-1793$.
Granizo, T., Pacheco, C., Ribadeneira, M. V., Guerrero, M. and Suárez, L., eds. (2002) Libro rojo de las aves del Ecuador. Quito: SIMBIOE,Conservación Internacional, EcoCiencia, Ministerio del Ambiente, UICN.

Graves, G. R. (1980) A new species of metaltail hummingbird from northern Peru. Wilson Bull. 92: 1-7.

Graves, G. R. (1985) Elevational correlates of speciation and intraspecific geographic variation in plumage in Andean forest birds. Auk 102: 556-579.

Harden, C. and Borrero, A. L. (2005) Report on the geomorphology of Parque Nacional Cajas. Technical report. Cuenca, Ecuador: Parque Nacional Cajas.

Hejl, S. J., Verner, J. and Bell, G. W. (1990) Sequential versus initial observations in studies of avian foraging. Stud. Avian Biol. 13: 166-173.

Hernandez, P. A., Graham, C. H., Master, L. L. and Albert, D. (2006) The effect of sample size and species characteristics on performance of different species distribution modeling methods. Ecography 29: 773-785.

Hijmans, R. J., Cameron, S. E., Parra, J. L., Jones, P. G. and Jarvis, A. (2005) Very high resolution interpolate climate surface for global land areas. Int. J. Climatol. 25: 19651978.

Hobson, K., Wassenaar, L. I., Milá, B., Lovette, I., Dingle, C. and Smith, T. B. (2003) Stable isotopes as indicators of distribution movements in an Ecuadorian hummingbird community. Oecologia 136: 302-308.

Humple, D., Nur, N., Geupel, G. R. and Lynes, M. P. (2001) Female-biased sex ration in a wintering population of Ruby-crowned Kinglets. Wilson Bull. 113: 419-424.

IERSE 2004. Estaciones meteorológicas de la cuenca del río Paute. Cuenca, Ecuador: Universidad del Azuay.

Jorgensen, P. M., Ulloa, C., Madsen, J. E. and Valencia, R. (1995) A floristic analysis of the high Andes of Ecuador: biodiversity and conservation of Neotropical montane forest. Pp. 221-237 in S. Churchill, H. Balslev, E. Forero and J. Luteyn, eds. Biodiversity and conservation of Neotropical montane forest. New York: New York Botanical Garden. 
Jorgensen, P. M. and León-Yánez, S., eds. (1999) Catalogue of the vascular plants of Ecuador. Monogr. Syst. Bot. Mo. Bot. Gard. 75: 1-1182.

King, J. R. (1989) Notes on the birds of the Río Mazan Valley, Azuay province Ecuador, with special reference to Leptosittaca branickii, Hapalopsittaca amazonina pyrrhops and Metallura baroni. Bull. Brit. Ornithol. Club 109: 140-147.

Kuban, J. F. and Neill, R. L. (1980) Feeding ecology of hummingbirds in the highlands of the Chisos Mountains, Texas. Condor 82: $180-185$.

Latta, S. C. and Baltz, M. (1997) Population limitation in Neotropical migratory birds: comments on Rappole and McDonald. Auk I14: 754-762.

Loiselle, B. A., Howell, C. A., Graham, C. H., Goerck, J. M., Brooks, T., Smith, K. G. and Williams, P. H. (2003) Avoiding pitfalls of species distribution models in conservation planning. Conserv. Biol. 17: 15911600 .

López-Ornat, A. L. and Greenberg, R. (1990) Sexual segregation by habitat by migratory warblers in Quintana Roo, Mexico. Auk 107: 539-543.

Lui, C. R., Berry, P. M., Dawson, T. P. and Pearson, R. G. (2005) Selecting thresholds of occurrence in the prediction of species distributions. Ecography 28: 385-393.

Martínez, J. P., Tinoco, B. and Arbeláez, E. (2005) Expediente para la nominación del Parque Nacional Cajas a patrimonio mundial. Componente zoología. Technical report. Cuenca, Ecuador: Universidad del Azuay.

Matheus, J. C. (2002) Metallura Gorjivioleta (Metallura baroni). P. 148 in T. Granizo et al., eds. Libro rojo de las aves del Ecuador. Quito: SIMBIOE, Conservación Internacional, EcoCiencia, Ministerio del Ambiente, UICN.

Ortiz-Crespo, F. (1984) First twentiethcentury specimen of the Violet-throated Metaltail Metallura baroni. Bull. Brit. Orn. Club 10: 95-97.

Pérez-Emán, J. L. (2005) Molecular phylogenetics and biogeography of the Neotropical redstarts (Myioborus; Aves, Parulinae), Mol. Phylogenet. Evol. 37: 511-528.
Petit, L. J. and Petit, D. R. (1996) Factors governing habitat selection by Prothonotary Warblers: field test of the FretwellLucas models. Ecol. Monogr. 66: 367-387.

Phillips, J. S., Anderson, P. R. and Schapire, R. E. (2006) Maximum entropy modeling of species geographic distributions. Ecol. Model. 190: 231-259.

Poulsen, B. O. and Krabbe, N. (1998) Avifaunal diversity of five high-altitude cloud forests on the Andean western slope of Ecuador: testing a rapid assessment method. J. Biogeogr. 25: 83-93.

Remsen, J. V. and Robinson, S. (1990) A classification scheme for foraging behaviour of birds on terrestrial habitats. Stud. Avian Biol. 13: 144-160.

Remsen, J. V., Stiles, G. F. and Scott, P. E. (1986) Frequency of arthropods in stomachs of tropical hummingbirds. Auk 103: 436-441.

Ridgely, R. S. and Greenfield, P. (2001) The birds of Ecuador. Status, distribution and taxonomy. Ithaca, NY: Cornell University Press.

Rodas, F. (1998) Aves del bosque de Mazán. Vol. II. Cuenca, Ecuador: ETAPA.

Rodas, F. (2001). La evaluacion de impacto ambiental como base para la gestión de las áreas de bosque y vegetación protectora Fierroloma y Dudahuayco; Azuay, Ecuador. Tesis de Licenciatura. Cuenca, Ecuador: Universidad del Azuay.

Rodas, F. and Tinoco, B. (2003) Análisis de la avifauna del Parque Nacional Cajas y su aplicación como herramienta de conservación. Technical report. Cuenca, Ecuador: Consultoría para el Plan del Manejo del Parque Nacional Cajas (CEMAPRIMES).

Soberón, J. and Peterson, A. T. (2004) Biodiversity informatics: managing and applying primary biodiversity data. Phil. Trans. R. Soc. Lond. B. 359: 689-698.

Stiles, F. G. (1995) Behavioral, ecological and morphological correlates of foraging for arthropods by the hummingbirds of a tropical wet forest. Condor 97: 853-878.

Van Horne, B (1983) Density as a misleading indicator of habitat quality. J. Wildl. Manage. 47: 893-901.

Vanacker, V., Molina, A., Govers, G., Poesen, J. and Deckers, J. (2007) Spatial variation of suspended sediment concentrations in a 
tropical Andean river system: the Paute river, southern Ecuador. Geomorphology 87: 53-67.

Weir, J. T. (2006) Divergent timing and patterns of species accumulation in lowland and highland Neotropical birds. Evolution 6o: $842-855$.

White, S. and Maldonado, F. (1991) The use and conservation of natural resources in the Andes of southern Ecuador. Mt. Res. Dev. 11: $37-55$.
Wiegand, T., Revilla, E. and Moloney, K. (2005) Effects of habitat loss and fragmentation on population dynamics. Conserv. Biol. 19: 108-121.

Wolf, F. L., Stiles, G. F. and Hainsworth, F. R. (1976) Ecological organization of a tropical highland hummingbird community. J. Anim. Ecol. 32: 349-379.

Zar, J. 1984. Biostatistical analysis. Second Edition. New Jersey, USA: Prentice Hall.

BORIS A. TINOCO*, PEDRO X. ASTUDILLO

Escuela de Biología del Medio Ambiente, Universidad del Azuay, Cuenca, Ecuador.

STEVEN C. LATTA

National Aviary, Allegheny Commons West, Pittsburgh, Pennsylvania, 15212, U.S.A.

CATHERINE H. GRAHAM

Department of Ecology and Evolution, 636 Life Science Building, Stony Brook University, Stony Brook, New York, 11794, U.S.A.

*Author for correspondence; e-mail: boristmr@yahoo.com

Received 8 December 2007; revision accepted 31 March 2008 